\title{
Toxicity and Resistance Potential of Selected Fungicides to Galactomyces and Penicillium spp. Causing Postharvest Fruit Decays of Citrus and Other Crops
}

\author{
A. H. McKay, H. Förster, and J. E. Adaskaveg, Department of Plant Pathology and Microbiology, University of California, Riverside \\ 92521
}

\begin{abstract}
McKay, A. H., Förster, H., and Adaskaveg, J. E. 2012. Toxicity and resistance potential of selected fungicides to Galactomyces and Penicillium spp. causing postharvest fruit decays of citrus and other crops. Plant Dis. 96:87-96.

A diverse collection of isolates of Galactomyces citri-aurantii and $G$. geotrichum, the causal pathogens of sour rots of citrus and other fruit crops, respectively, was evaluated for sensitivity to demethylationinhibiting (DMI) fungicides of the triazole group. Propiconazole was found to be highly effective in reducing mycelial growth of both species in vitro. For 139 isolates of G. citri-aurantii, a mean effective concentration for $50 \%$ reduction of mycelial growth $\left(\mathrm{EC}_{50}\right.$ value) of $0.34 \mu \mathrm{g} / \mathrm{ml}$ was determined; whereas, for 33 isolates of G. geotrichum, this value was $0.14 \mu \mathrm{g} / \mathrm{ml}$. In a comparison of additional DMI fungicides, mean $\mathrm{EC}_{50}$ values for 60 isolates of $G$. citri-aurantii and 20 isolates of G. geotrichum, were 0.27 and $0.17 \mu \mathrm{g} / \mathrm{ml}$ for cyproconazole, 0.25 and $0.14 \mu \mathrm{g} / \mathrm{ml}$ for metconazole, and 1.16 and $0.73 \mu \mathrm{g} / \mathrm{ml}$ for tebuconazole, respectively. Propiconazole was also highly active against mycelial growth of imazalil-sensitive isolates of Penicillium digitatum, the pathogen that causes green mold of citrus, with a mean

$\mathrm{EC}_{50}$ value of $0.008 \mu \mathrm{g} / \mathrm{ml}$ for 63 isolates. Imazalil-resistant isolates of this fungus were cross-resistant to propiconazole. When G. citri-aurantii and $P$. digitatum were grown at selected $\mathrm{pH}$ values between 3 and 9 , inhibition by propiconazole occurred over the entire $\mathrm{pH}$ range. The fungicide was most effective at $\mathrm{pH} 5$ when compared with the nonfungicide-amended control grown at the same $\mathrm{pH}$. In laboratory mass platings of single-spore isolates sensitive to propiconazole onto selective media, isolates with an up to 81.6-fold decrease in sensitivity to the fungicide were recovered for $P$. digitatum. For $G$. geotrichum, isolates with an approximately twofold decrease in sensitivity were obtained. No isolates with reduced sensitivity were recovered for $G$. citri-aurantii. Propiconazole is currently being registered for postharvest use on citrus and other crops, and the information provided will be valuable in monitoring of fungicide resistance and in designing effective fungicide application strategies.
\end{abstract}

The sterol biosynthesis or demethylation inhibitor (DMI) propiconazole is a new postharvest fungicide in the United States that is currently being registered on citrus, stone fruit, and other fruit crops such as tomato. It is highly effective against several important decays, including those caused by species of Penicillium, Rhizopus, and Monilinia. Most importantly, it is effective against sour rots caused by Galactomyces citri-aurantii E.E. Butler (anamorph: Geotrichum citri-aurantii (Ferraris) E.E. Butler) on citrus fruit and by Galactomyces geotrichum E.E. Butler \& L.J. Petersen (anamorph: Geotrichum candidum Link) on stone fruit, tomato, and other crops $(2,11)$.

The two sour rot pathogens are yeast-like fungi that commonly occur in soils $(8,9)$. Conidia are disseminated by water splash from irrigation or rain, by wind in dust particles, or by insects and other animals to the surface of fruit where they can cause infections at sites of injury $(7,15,16,26)$. Although sour rot can occur on fruit in the field, it is most economically important as a postharvest decay. On citrus in California, the disease is particularly destructive on lemon, grapefruit, and mandarin that, depending on market demands, are often stored for prolonged periods at relatively high temperatures $\left(12\right.$ to $15^{\circ} \mathrm{C}$ ) and at high relative humidity (92 to $98 \%)(3,4,7,16,46)$. Endo-polygalacturonases excreted by the pathogen rapidly macerate the fruit tissue, and juices dripping onto healthy fruit can spread the decay in storage (12). Outbreaks of

Corresponding author: J. E. Adaskaveg, E-mail: jim.adaskaveg@ucr.edu

Current address of A. H. McKay: The New Zealand Institute for Plant \& Food Research Ltd., Mount Albert Research Centre, Private Bag 92169, Auckland 1142, New Zealand.

Accepted for publication 18 August 2011.

http://dx.doi.org/10.1094/PDIS-06-11-0466

(C) 2012 The American Phytopathological Society sour rot on stone fruit have caused economic losses in the United States. In California, propiconazole received successive emergency registrations for managing sour rot of peaches and nectarines from 2005 to 2011.

Decay of citrus fruit by species of Penicillium is an ongoing major problem for citrus industries worldwide. Green mold caused by Penicillium digitatum (Pers.) Sacc. is the most important postharvest disease of citrus produced in semiarid climates like California (19). The pathogen produces very large numbers of aerially dispersed conidia that contaminate virtually every fruit in citrus orchards and packinghouses $(19,28)$. As is the case for Galactomyces spp., fruit injuries are required for infection by $P$. digitatum and these occur commonly during harvest and postharvest handling $(16,19)$. Thus, handling practices that minimize fruit injuries are important to decrease the incidence of decay. Additionally, sanitation treatments that reduce the level of inoculum and postharvest fungicides are essential components in the integrated management of these decays. On citrus, several compounds, each with a different mode of action, are currently registered for postharvest use in the United States. These include the DMI-imidazole imazalil and the methyl benzimidazole carbamate thiabendazole that have been used for more than 30 years. The anilinopyrimidine pyrimethanil, the quinone outside inhibitor (QoI) azoxystrobin, and the phenylpyrrole fludioxonil are recently registered postharvest fungicides. All these compounds are primarily used to manage citrus green mold. Only sodium ortho-phenylphenate (SOPP), a phenolic-based fungicide, has some efficacy against sour rot, but concentrations required to effectively manage the decay can be phytotoxic (7). Furthermore, use of SOPP has been in decline over recent years due to disposal and human safety concerns (44). Guazatine, a guanidine fungicide used in other parts of the world, has very good efficacy against sour rot (48) but will not be registered in the United States due to its multiple active ingredients and difficulty in measuring chemical residues on fruit. Thus, no effective postharvest fungicide is currently available to the United States citrus industry for the management of sour rot. 
Preliminary screening of several DMI-triazole fungicides for toxicity to Galactomyces citri-aurantii identified propiconazole and cyproconazole as highly toxic to the pathogen, whereas metconazole and tebuconazole were less effective (36). Due to the stereochemical nature of DMI compounds and site-specific binding to the cytochrome P450 14 $\alpha$-demethylase enzyme, this class of fungicides can have different specificities to the target site within and among different organisms (32). Their activity against $G$. geotrichum is not known and cross-resistance to the DMI-imidazole imazalil has not been evaluated.

Fungicide efficacy in the postharvest environment is dependent on a variety of factors, including application method, use of fruit coatings and additives, as well as $\mathrm{pH}$ of treatment solutions. For example, to maintain decay control efficacy and minimize phytotoxicity on treated citrus fruit, SOPP should be applied at a $\mathrm{pH}$ between 11.7 and 12.0 (19). For imazalil, a pH of 7.5 was found to be more effective in reducing green mold incidence of inoculated lemon fruit than a $\mathrm{pH}$ of 4.0 (43). This information needs to be obtained for any fungicide, including propiconazole, before large-scale commercial use.

The prolonged use of single chemistries to control diseases has resulted in the development of resistance in many fungal pathogens $(13,14,22)$. For example, the California citrus industry has experienced significant economic losses due to reduced efficacy of imazalil and thiabendazole as well as biphenyl and SOPP against Penicillium decays $(17,19,24,25)$. A practical tool in estimating the risk of pathogen populations for developing resistance is knowledge of the intrinsic resistance potential or resistance frequency to a specific fungicide. For example, resistance frequencies have been established for $P$. digitatum against pyrimethanil, azoxystrobin, and fludioxonil and these data helped in the design of best management strategies, with the goal to maintain the long-term utility of these fungicides (30). Information on natural resistance frequencies has not been obtained for propiconazole.

Objectives of this research focused on the use of propiconazole as a new tool for the management of postharvest decays, with a focus on the specific needs of the citrus and stone fruit industries, and included (i) evaluation of sensitivities of G. citri-aurantii and G. geotrichum to propiconazole compared with selected other DMI-triazole fungicides (metconazole, cyproconazole, and tebuconazole); (ii) evaluation of the effect of $\mathrm{pH}$ on the activity of propiconazole against $P$. digitatum and $G$. citri-aurantii; iii) evaluation of cross-resistance in imazalil-resistant isolates of $P$. digitatum to propiconazole; and iv) estimation of natural resistance frequencies in populations of $P$. digitatum, G. citri-aurantii, and $G$. geotrichum to propiconazole, as well as characterization of resistant isolates that may be recovered in these studies.

\section{Materials and Methods}

Fungicides. Fungicides used include the DMI-triazoles cyproconazole (Alto 100SL; Syngenta Crop Protection, Greensboro, NC), difenoconazole (Inspire; Syngenta Crop Protection), fenbuconazole (Indar 75WSP; Dow AgroSciences, Indianapolis, IN), metconazole (Quash 50WDG; Valent USA, Walnut Creek, CA), myclobutanil (Laredo EC; Dow AgroSciences), propiconazole (Mentor 45WP; Syngenta Crop Protection), tebuconazole (Elite 45WP, Bayer CropScience, Research Triangle Park, NC), and tetraconazole (Eminent 125SL, Sipcam Agro USA, Durham, NC), as well as several fungicides registered for postharvest use in the United States: the DMI-imidazole imazalil (Freshgard 700; JBT FoodTech, Chicago, IL), the QoI azoxystrobin (Abound 2F; Syngenta Crop Protection), the phenylpyrrole fludioxonil (Scholar 50WP; Syngenta Crop Protection), the anilinopyrimidine pyrimethanil (Penbotec 400SC; Janssen Pharmaceutica, Titusville, $\mathrm{NJ}$ ), and the methyl benzimidazole carbamate thiabendazole (Decco Salt No. 19; Decco US Post-Harvest, Inc., Monrovia, CA).

Collection and maintenance of fungal isolates. In total, 125 isolates of $G$. citri-aurantii were recovered from soil samples from citrus groves or from symptomatic citrus fruit in packinghouses throughout the citrus-growing areas of California (Table 1). Eleven isolates of G. geotrichum were obtained from soil samples in citrus or nectarine orchards or from peach fruit in packinghouses in California (Table 2). An additional 14 isolates of G. citri-aurantii and 22 isolates of $G$. geotrichum of worldwide origin came from the collection of Dr. E. E. Butler, University of California, Davis. Isolates of $P$. digitatum were chosen randomly from a previous study (Table 3) (29).

Isolations of Galactomyces spp. from symptomatic fruit were made by excising a small tissue section below the epidermal area at the margin of a decay lesion and plating onto potato dextrose agar (PDA; Difco Laboratories, Detroit, MI) amended with fludioxonil at $1 \mu \mathrm{g} / \mathrm{ml}$ and novobiocin at $500 \mu \mathrm{g} / \mathrm{ml}$ (Sigma-Aldrich, St. Louis,

Table 1. Isolates of Galactomyces citri-aurantii used in this study ${ }^{\mathrm{z}}$

\begin{tabular}{|c|c|c|c|c|c|}
\hline Isolate number & Number of isolates & Collection date & Source & Sample location & Geographic origin \\
\hline 1 & 1 & 2007 & Grapefruit fruit & Packinghouse & Ventura County, CA \\
\hline $2-4$ & 3 & 2006 & Lemon fruit & Packinghouse & Kern County, CA \\
\hline $5-6$ & 2 & 2006 & Lemon fruit & Packinghouse & Riverside County, CA \\
\hline $7-10$ & 4 & 2006-2009 & Lemon fruit & Packinghouse & Tulare County, CA \\
\hline $11-54$ & 44 & 2006-2008 & Lemon fruit & Packinghouse & Ventura County, CA \\
\hline $55-58$ & 4 & 2009 & Mandarin fruit & Packinghouse & Kern County, CA \\
\hline 59 & 1 & 2006 & Navel orange fruit & Packinghouse & Riverside County, CA \\
\hline $60-62$ & 3 & 2007 & Navel orange fruit & Packinghouse & Tulare County, CA \\
\hline 63 & 1 & 2006 & Valencia orange fruit & Packinghouse & Riverside County, CA \\
\hline $64-65$ & 2 & 2006 & Valencia orange fruit & Packinghouse & Tulare County, CA \\
\hline $66-83$ & 18 & 2007,2008 & Soil & Lemon grove & Ventura County, CA \\
\hline 84 & 1 & 2007 & Soil & Navel orange grove & Kern County, CA \\
\hline $85-120$ & 36 & 2008 & Soil & Navel orange grove & Tulare County, CA \\
\hline $121-124$ & 4 & 2007,2008 & Soil & Valencia orange grove & Tulare County, CA \\
\hline 125 & 1 & 2007 & Soil & Valencia orange grove & Ventura County, CA \\
\hline $126-127$ & 2 & NA & Soil & NA & Argentina \\
\hline 128 & 1 & NA & Soil & NA & Florida \\
\hline $129-130$ & 2 & NA & Soil & NA & China \\
\hline $131-132$ & 2 & NA & Soil & NA & Israel \\
\hline 133 & 1 & NA & Soil & NA & Mexico \\
\hline 134 & 1 & NA & Soil & NA & China \\
\hline 135 & 1 & NA & Soil & NA & Trinidad \\
\hline 136 & 1 & NA & Soil & NA & Texas \\
\hline 137 & 1 & NA & NA & NA & NA \\
\hline $138-139$ & 2 & NA & NA & NA & NA \\
\hline Total & 139 & $\ldots$ & $\ldots$ & $\ldots$ & $\ldots$ \\
\hline
\end{tabular}

${ }^{\mathrm{z}} \mathrm{NA}$ indicates information not available. 
MO). Soil samples were collected 5 to $10 \mathrm{~cm}$ below the soil surface in commercial orchards in central and southern California and in southwestern Arizona. Each composite sample consisted of 10 soil cores that were collected around the drip line from each of 5 to 10 trees per orchard. Isolations from soil were done using a procedure by Eckert and Butler (18) modified as follows: an aliquot of $3 \mathrm{~g}$ of soil was placed into 100-ml Erlenmeyer flasks containing $25 \mathrm{ml}$ of sterile water and was shaken at $150 \mathrm{rpm}$ on an orbital shaker for $2 \mathrm{~h}$ to loosen conidia and mycelium from the soil particles. Aliquots of $1 \mathrm{ml}$ were added to sterile tubes containing $25 \mathrm{ml}$ of autoclaved lemon juice and incubated on a shaker at 200 $\mathrm{rpm}$ for $48 \mathrm{~h}$ at $24^{\circ} \mathrm{C}$. Aliquots of $50 \mu \mathrm{l}$ of this mixture were spread onto PDA amended with fludioxonil at $1 \mu \mathrm{g} / \mathrm{ml}$ and novobiocin at $500 \mu \mathrm{g} / \mathrm{ml}$ using a spiral plater (Autoplate 4000; Spiral Biotech, Norwood, MA) set at the exponential deposition mode. After 48 to $72 \mathrm{~h}$, colonies resembling Galactomyces spp. were excised and spread onto PDA for single-spore isolation. Identification of each isolate was confirmed using a lemon juice incubation test (46) and by polymerase chain reaction (PCR) (37). Between one and three isolates per orchard site were used for determining fungicide sensitivities.

Fungal isolates were maintained on PDA, and conidia used for fungicide sensitivity assays were obtained from 4- to 7-day-old cultures. Stock cultures were stored for up to 1 year in sterile water at $4^{\circ} \mathrm{C}$. For this, a conidial suspension (approximately $50 \mu \mathrm{l}$ of $1 \times$ $10^{6} \mathrm{conidia} / \mathrm{ml}$ ) of each isolate was spread onto 6-cm PDA plates and incubated for 48 to $72 \mathrm{~h}$, and four to six mycelial plugs $(5 \mathrm{~mm}$ in diameter) were transferred into 2-ml microcentrifuge tubes containing $1 \mathrm{ml}$ of sterile water.

Determination of effective concentrations for $50 \%$ reduction of mycelial growth and conidial germination using the spiral gradient dilution method. The spiral gradient dilution (SGD) method was performed as described previously and, for measure- ment of mycelial growth, plates were inoculated with myceliumcovered cellophane strips (21). Sixteen randomly selected isolates of each G. citri-aurantii and G. geotrichum were used to determine effective concentrations for $50 \%$ reduction $\left(\mathrm{EC}_{50}\right.$ values) of mycelial growth and conidial germination for the eight DMI-triazole fungicides listed above. The most effective fungicides were then tested against an expanded set of isolates: 139 and 33 isolates were tested against propiconazole, and 60 and 20 isolates were tested against cyproconazole, metconazole, and tebuconazole for G. citri-aurantii and G. geotrichum, respectively. For P. digitatum, 63 and 37 isolates were evaluated for mycelial growth inhibition by propiconazole and imazalil, respectively. Fungicide dilutions were prepared in sterile water. Concentrations applied to $15-\mathrm{cm}$ agar plates by the spiral plater for the Galactomyces spp. were 500 (range of actual concentration in agar $=0.03$ to 3.50), 1,000 (range: 0.06 to 7.00 ), 1,250 (range: 0.07 to 8.80 ), and 1,500 (range: 0.09 to $10.50) \mu \mathrm{g} / \mathrm{ml}$ for cyproconazole, propiconazole, metconazole, and tebuconazole, respectively, and was 5,000 (range: 0.29 to 35 ) $\mu \mathrm{g} / \mathrm{ml}$ for the remaining fungicides. For $P$. digitatum, 20 (range: 0.001 to 0.140 ) and 1,000 (range: 0.06 to 7.00$) \mu \mathrm{g} / \mathrm{ml}$ were used for propiconazole and 30 (range: 0.002 to 0.210 ) and 1,000 (range: 0.06 to 7.00$) \mu \mathrm{g} / \mathrm{ml}$ were used for imazalil for DMI-sensitive and -resistant isolates, respectively.

For determining $\mathrm{EC}_{50}$ values for conidial germination, conidial suspensions $\left(10^{6}\right.$ conidia/ml $)$ were streaked radially along the concentration gradient. Conidial germination was evaluated after $20 \mathrm{~h}$ under a microscope by establishing the point along the radial streak at which $50 \%$ of the conidia within the field of view had germinated. A conidium was considered germinated when the germ tube exceeded twice the diameter of the conidium. Two or three replicate plates were prepared for each fungicide and fungal isolate per experiment, and each fungicide-isolate combination was evaluated twice.

Table 2. Isolates of Galactomyces geotrichum used in this study ${ }^{\mathrm{z}}$

\begin{tabular}{|c|c|c|c|c|c|}
\hline Isolate number & Number of isolates & Collection date & Source & Sample location & Geographic origin \\
\hline $1-5$ & 5 & 2007,2008 & Soil & Citrus orchard & Ventura County, CA \\
\hline $6-11$ & 6 & $1957,1963,1969,1984,1986$ & Soil & NA & California \\
\hline 12 & 1 & 1986 & Soil & Orange grove & Yolo County, CA \\
\hline 13 & 1 & 1973 & Soil & NA & Pennsylvania \\
\hline 14 & 1 & 1968 & Soil & NA & Puerto Rico \\
\hline 15 & 1 & NA & Soil & NA & Riverside County, CA \\
\hline 16 & 1 & 1963 & Soil & NA & Brazil \\
\hline 17 & 1 & 1981 & Soil & Citrus grove & Costa Rica \\
\hline $18-19$ & 2 & 1963 & Soil & NA & Egypt \\
\hline $20-21$ & 2 & 1974 & Soil & Guava planting & India \\
\hline 22 & 1 & 1963 & Soil & NA & Israel \\
\hline $23-25$ & 3 & 1963 & Soil & NA & Japan \\
\hline 26 & 1 & 1970 & Soil & Orange grove & Turkey \\
\hline 27 & 1 & 1963 & Soil & NA & Rhodesia \\
\hline $28-32$ & 5 & $2000,2005,2006$ & Peach fruit & Packinghouse & Fresno County, CA \\
\hline 33 & 1 & 2008 & Soil & Nectarine orchard & Fresno County, CA \\
\hline Total & 33 & $\ldots$ & $\ldots$ & $\ldots$ & $\ldots$ \\
\hline
\end{tabular}

${ }^{\mathrm{z}} \mathrm{NA}$ indicates information not available.

Table 3. Isolates of Penicillium digitatum used in this study

\begin{tabular}{lccll}
\hline Isolate number & Number of isolates & Collection date & Source (fruit) & Geographic origin \\
\hline $1-2$ & 2 & 2003 & Navel orange & Fresno County, CA \\
3 & 1 & 2004 & Navel orange & Kern County, CA \\
$4-9$ & 6 & 2003,2004 & Lemon & Kern County, CA \\
$10-15$ & 6 & 2003,2004 & Navel orange & Riverside County, CA \\
$16-27$ & 12 & 2003,2004 & Remon & Riverside County, CA \\
$28-30$ & 3 & 2003 & Grapefruit & Riverside County, CA \\
31 & 1 & 2003 & Navel orange & San Bernardino County, CA \\
$32-36$ & 5 & 2003 & Navel orange & Tulare County, CA \\
$37-46$ & 10 & 2003 & Lemon & Ventura County, CA \\
$47-54$ & 8 & 2003,2004 & Lemon & Yuma County, AZ \\
$55-63$ & 9 & 2003,2004 & Lemon & $\ldots$ \\
Total & 63 & $\ldots$ & $\ldots$ & $\ldots$ \\
\hline
\end{tabular}


Effect of pH on activity of propiconazole against $G$. citri-aurantii and $\boldsymbol{P}$. digitatum. Conidia of $G$. citri-aurantii (isolate Gca 46, accession number AN4088) or P. digitatum (isolate 8, AN3180) at a final concentration of $1 \times 10^{6} \mathrm{conidia} / \mathrm{ml}$ were added to potato dextrose broth (PDB; Difco Laboratories) that was buffered by adding $2 \mathrm{ml}$ of sterilized citrate buffer per $35 \mathrm{ml}$ of broth (35). Propiconazole concentrations used $(0.458 \mu \mathrm{g} / \mathrm{ml}$ for G. citri-aurantii and $0.008 \mu \mathrm{g} / \mathrm{ml}$ for $P$. digitatum) inhibited mycelial growth using the SGD method by approximately $75 \%$. The $\mathrm{pH}$ was adjusted to $3,5,7$, or 9 using $1 \mathrm{~N} \mathrm{HCl}$ or $\mathrm{NaOH}$ and was measured with a $\mathrm{pH}$ meter (Orion 5 Star; Thermo Fisher Scientific Inc., Waltham, MA). Aliquots of $0.2 \mathrm{ml}$ of the suspensions were transferred into a sterile 96-well microtiter plate and the plate was placed on an orbital shaker at $180 \mathrm{rpm}$ at $25^{\circ} \mathrm{C}$. The absorbance at $490 \mathrm{~nm}$ was measured at the beginning of the experiment and after $18 \mathrm{~h}$ (G. citri-aurantii) or $24 \mathrm{~h}$ ( $P$. digitatum) using a plate reader (Wallac Victor ${ }^{2} 1420$ Multilabel Counter; PerkinElmer Life Sciences, Boston, MA). The initial optical density readings were subtracted from the final readings and the resulting values represented an estimate of growth at each $\mathrm{pH}$. Each treatment was replicated four times and the experiment was done three times.

Estimation of resistance frequencies against propiconazole in populations of $G$. citri-aurantii, G. geotrichum, and P. digitatum in laboratory selection studies. Conidial suspensions were prepared from randomly selected single-spore isolates that were all determined to be sensitive to propiconazole. Eleven isolates were used for G. citri-aurantii $\left(5 \times 10^{8}\right.$ conidia/ml $), 12$ isolates for $G$. geotrichum $\left(5 \times 10^{7}\right.$ conidia/ml $)$, and 12 isolates for $P$. digitatum $(1$ $\times 10^{8}$ conidia $/ \mathrm{ml}$ ). For $G$. citri-aurantii, a mixture of equal amounts of conidia from each of the 11 isolates were also prepared. PDA plates $15 \mathrm{~cm}$ in diameter were amended with propiconazole using the spiral plater set at the exponential deposition mode. Concentrations were chosen to locate the mean $\mathrm{EC}_{95}$ value for each species approximately 10 to $15 \mathrm{~mm}$ from the margin of each plate and these were propiconazole at 3,000 (range: 0.17 to 21.01), 1500 (range: 0.09 to 10.50), and 100 (range: 0.006 to $0.700) \mu \mathrm{g} / \mathrm{ml}$ for G. citri-aurantii, G. geotrichum, and P. digitatum, respectively. After 2 to $4 \mathrm{~h}, 60 \mu \mathrm{l}$ of the conidial suspensions were spread evenly onto the agar plates using the spiral plater in the "lawn" deposition mode (uniform deposition across plate). This resulted in a total number of conidia for each of two replicate plates of $3 \times 10^{7}, 3 \times 10^{6}$, and $6 \times 10^{7}$ for the three fungi, respectively. After 7 days of incubation for G. citri-aurantii and $G$. geotrichum and 3 days for $P$. digitatum at $24^{\circ} \mathrm{C}$, white cottony colonies greater than $1 \mathrm{~mm}$ in diameter for the two Galactomyces spp. and green sporulating colonies for $P$. digitatum were quantified on each plate, and the position as distance from the center of the plate was recorded. A subset of up to eight colonies per selection plate for each species was transferred to nonamended PDA plates using a sterile toothpick, recultured, and then evaluated for sensitivity to propiconazole using the SGD method at the appropriate concentration. The change in fungicide sensitivity compared with the original isolate was expressed as the resistance factor and was calculated as $\mathrm{EC}_{50}$ value of the putative resistant isolate/EC $\mathrm{EC}_{50}$ value of the original isolate. When resistance was detected, the resistance frequency was calculated as the proportion of the number of resistant colonies recovered of the total number of conidia plated.

Estimation of natural resistance frequencies to propiconazole in populations of $\boldsymbol{G}$. citri-aurantii from lemon grove soils. Soil samples from 10 lemon groves in Ventura County, CA, were obtained as described above in the winter season when wet conditions commonly occur in California. Samples from all sites within each grove were combined for a total of 10 composite samples for the 10 groves. Samples were processed as described above, except that fludioxonil at $1 \mu \mathrm{g} / \mathrm{ml}$ was added to the soil-lemon juice mixture that was shaken for $24 \mathrm{~h}$. Propiconazole $(3,000 \mu \mathrm{g} / \mathrm{ml})$ was spirally applied in the exponential mode to $15-\mathrm{cm}$ PDA plates amended with fludioxonil at $1 \mu \mathrm{g} / \mathrm{ml}$ and novobiocin at $500 \mu \mathrm{g} / \mathrm{ml}$. Using this concentration of propiconazole, a radial concentration range of $0.2 \mu \mathrm{g} / \mathrm{ml}$ at the perimeter of the plate to $30 \mu \mathrm{g} / \mathrm{ml}$ at the center of the plate is obtained. After 2 to $4 \mathrm{~h}$, the soil-lemon juice mixture was applied using the spiral plater set for the "lawn" deposition mode. After 4 days of incubation at $24^{\circ} \mathrm{C}$, colonies characteristic of $G$. citri-aurantii growing in the higher propiconazole concentration range were transferred to PDA plates using sterile toothpicks and were evaluated for their sensitivity against propiconazole using the SGD method.

Statistical analysis of data. For repeated experiments, homogeneity of variances was tested using Bartlett's test of homogeneity. Because variances were homogeneous for each experiment, data were combined and further statistically analyzed (SAS version 9.1; SAS Institute Inc., Cary, NC). Nontransformed and transformed $\left(\log _{10}\right)$ mean $\mathrm{EC}_{50}$ values as well as resistance factors were compared using analysis of variance (ANOVA) or general linear model and least significant difference (LSD) mean separation procedures of SAS.

Mean $\mathrm{EC}_{50}$ values for populations of each fungal species were plotted in frequency histograms. For this, $\mathrm{EC}_{50}$ values were first $\log _{10}$-transformed and the bin (i.e., $\mathrm{EC}_{50}$ category) width $h$ for the

Table 4. Effective concentrations for $50 \%$ reduction of mycelial growth $\left(\mathrm{EC}_{50}\right.$ values) of isolates of Galactomyces citri-aurantii exposed to selected demethylation inhibitor (DMI)-triazole fungicides and currently registered postharvest fungicides of citrus

\begin{tabular}{llcr}
\hline Registration status, fungicide & \multicolumn{1}{c}{ Class $^{\mathbf{w}}$} & $\mathbf{E C}_{\mathbf{5 0}} \mathbf{r a n g e}(\boldsymbol{\mu g} / \mathbf{m l})^{\mathbf{x}}$ & $\mathbf{M e a n ~ E C}_{\mathbf{5 0}}(\boldsymbol{\mu g} / \mathbf{m l})^{\mathbf{y}}$ \\
\hline Experimental & & & $0.27 \mathrm{D}$ \\
Cyproconazole & DMI-triazole & $0.14-0.50$ & $2.30 \mathrm{C}$ \\
Difenoconazole & DMI-triazole & $1.29-5.99$ & $>29.3 \mathrm{~A}^{\mathrm{z}}$ \\
Fenbuconazole & DMI-triazole & $>29.3$ & $0.25 \mathrm{D}$ \\
Metconazole & DMI-triazole & $0.13-0.55$ & $10.30 \mathrm{~B}$ \\
Myclobutanil & DMI-triazole & $4.75-15.76$ & $0.34 \mathrm{D}$ \\
Propiconazole & DMI-triazole & $0.10-0.83$ & $1.16 \mathrm{D}$ \\
Tebuconazole & DMI-triazole & $0.40-2.21$ & $14.9 \mathrm{~B}$ \\
Tetraconazole & DMI-triazole & $6.6-39.9$ & $56.4 \mathrm{~B}^{\mathrm{z}}$ \\
Registered & & $55.3-57.5$ & $31.0 \mathrm{C}^{\mathrm{z}}$ \\
Azoxystrobin & QoI & $15.3-52.8$ & $32.7 \mathrm{C}^{\mathrm{z}}$ \\
Fludioxonil & Phenylpyrrole & $22.3-43.6$ & $>60.0 \mathrm{~A}^{\mathrm{z}}$ \\
Imazalil & DMI-imidazole & $>60.0$ & $66.1 \mathrm{~A}^{\mathrm{z}}$ \\
Pyrimethanil & Anilinopyrimidine & $62.0-68.4$ & \\
Thiabendazole & Methyl benzimidazole carbamate & & \\
\hline
\end{tabular}

${ }^{\mathrm{w}} \mathrm{QoI}=$ quinone outside inhibitor.

${ }^{\mathrm{x}} \mathrm{EC}_{50}$ values for inhibition of mycelial growth were determined using the spiral gradient dilution method. Mean values are based on 139 isolates for propiconazole; 60 isolates for cyproconazole, tebuconazole, and metconazole; and 16 isolates for all other fungicides.

y Statistical analyses were done separately for experimental and registered fungicides. Means followed by the same letter within a column are not significantly different $(P<0.01)$ following analysis of variance and least significant difference mean separation procedures.

${ }^{\mathrm{z}}$ Calculated $\mathrm{EC}_{50}$ value exceeds the water solubility of the fungicide active ingredient at $20^{\circ} \mathrm{C}$. 
transformed data was determined using the method of Scott (41) with the equation $h_{\mathrm{n}}=3.49 \mathrm{sn}^{-1 / 3}$, where $s$ is an estimate of the standard deviation and $n$ is the number of isolates used for each fungicide evaluated. Standard deviations were calculated from mean $\log _{10}$-transformed $\mathrm{EC}_{50}$ values for all isolates used in each fungicide evaluation. The number of bins was then determined over the range of $\mathrm{EC}_{50}$ values for each fungicide. Shapiro-Wilk probability values were calculated for $\log _{10}$-transformed values for each fungicide to determine whether data were normally distributed. For clarity, histograms were graphed using actual $\mathrm{EC}_{50}$ values.

To determine whether cross-resistance between imazalil and propiconazole was present in $P$. digitatum populations, mean $\log _{10^{-}}$ transformed $\mathrm{EC}_{50}$ values for each fungicide were plotted in pairwise comparisons. A regression analysis was then done using ANOVA and REG procedures (SAS version 9.1). The regression was graphed using actual $\mathrm{EC}_{50}$ values. Mean absorbance values from the $\mathrm{pH}$ study were graphed and standard errors for each $\mathrm{pH}$ value were determined. For comparisons of fungal growth in the presence or absence of propiconazole at each $\mathrm{pH}$ value for each fungal pathogen, data were analyzed using ANOVA and LSD procedures (SAS version 9.1).

\section{Results}

Sensitivities of mycelial growth and conidial germination of G. citri-aurantii and G. geotrichum to selected fungicides. Mean G. citri-aurantii $\mathrm{EC}_{50}$ values for eight DMI-triazole fungicides indicated that propiconazole, metconazole, cyproconazole, and tebuconazole were the most effective compounds, with $\mathrm{EC}_{50}$ values of $0.34 \mu \mathrm{g} / \mathrm{ml}$ (139 isolates; range of 0.10 to $0.83 \mu \mathrm{g} / \mathrm{ml}$ ), 0.25 $\mu \mathrm{g} / \mathrm{ml}$ (60 isolates; range of 0.13 to $0.55 \mu \mathrm{g} / \mathrm{ml}), 0.27 \mu \mathrm{g} / \mathrm{ml}(60$ isolates; range of 0.14 to $0.50 \mu \mathrm{g} / \mathrm{ml})$, and $1.16 \mu \mathrm{g} / \mathrm{ml}$ (60 isolates; range of 0.40 to $2.21 \mu \mathrm{g} / \mathrm{ml}$ ), respectively (Table 4). Fenbuconazole was the least effective fungicide, with an $\mathrm{EC}_{50}$ value of $>29.3$ $\mu \mathrm{g} / \mathrm{ml}$. Higher concentrations of this fungicide were not evaluated because these exceeded its water solubility. None of the currently registered postharvest citrus fungicides, including azoxystrobin, fludioxonil, imazalil, pyrimethanil, and thiabendazole, was effective against growth of the citrus sour rot pathogen, and $\mathrm{EC}_{50}$ values were all higher than $30 \mu \mathrm{g} / \mathrm{ml}$. $\log _{10}$-transformed $\mathrm{EC}_{50}$ values for the four most effective fungicides were normally distributed within the population as indicated by Shapiro-Wilk probability values of $P=0.502,0.579,0.372$, and 0.341 for propiconazole, metconazole, cyproconazole, and tebuconazole, respectively. The frequency distribution of $\mathrm{EC}_{50}$ categories as calculated by Scott's formula (41) for each fungicide is shown in the histograms of Figure 1A-D.

Propiconazole, cyproconazole, metconazole, and tebuconazole were also evaluated against conidial germination of G. citri-aurantii and mean $\mathrm{EC}_{50}$ values were determined to be $0.59,0.39,0.39$, and $1.57 \mu \mathrm{g} / \mathrm{ml}$, respectively. Values for the five registered citrus postharvest fungicides all exceeded $50 \mu \mathrm{g} / \mathrm{ml}$.

For isolates of $G$. geotrichum, mean $\mathrm{EC}_{50}$ values for mycelial growth inhibition for propiconazole (33 isolates), metconazole, cyproconazole, and tebuconazole (20 isolates for each fungicide) were $0.14,0.14,0.17$, and $0.73 \mu \mathrm{g} / \mathrm{ml}$, with ranges from 0.06 to $0.30,0.07$ to $0.22,0.06$ to 0.26 , and 0.29 to $1.69 \mu \mathrm{g} / \mathrm{ml}$, respectively. Shapiro-Wilk probability values were $P=0.729,0.279$, 0.129 , and 0.982 and, thus, $\log _{10}$-transformed values for each fungicide were normally distributed. The frequency distribution of $\mathrm{EC}_{50}$ categories for each fungicide is shown in the histograms of Figure 2A-D.

Sensitivity of mycelial growth of $P$. digitatum to propiconazole and imazalil, and cross-resistance between these fungicides. The frequency histograms for each of the two fungicides show the presence of two subpopulations among isolates of $P$. digitatum: one with high sensitivity and another one with reduced sensitivity (Fig. 3A and B). For the highly sensitive subpopulations, mean $\mathrm{EC}_{50}$ values were 0.008 and $0.005 \mu \mathrm{g} / \mathrm{ml}$, with ranges from 0.003 to 0.014 and 0.003 to $0.007 \mu \mathrm{g} / \mathrm{ml}$ for propiconazole and imazalil, respectively. For the less sensitive subpopulations, mean $\mathrm{EC}_{50}$ values were 0.487 and $0.103 \mu \mathrm{g} / \mathrm{ml}$, with ranges from 0.146 to 1.151 and 0.024 to $0.329 \mu \mathrm{g} / \mathrm{ml}$ for propiconazole and imazalil, respectively. Only $\log _{10}$-transformed values for the imazalil-sensitive subpopulation were normally distributed $(P=$ 0.294). The imazalil-resistant as well as the propiconazolesensitive and less sensitive subpopulations of $P$. digitatum were not
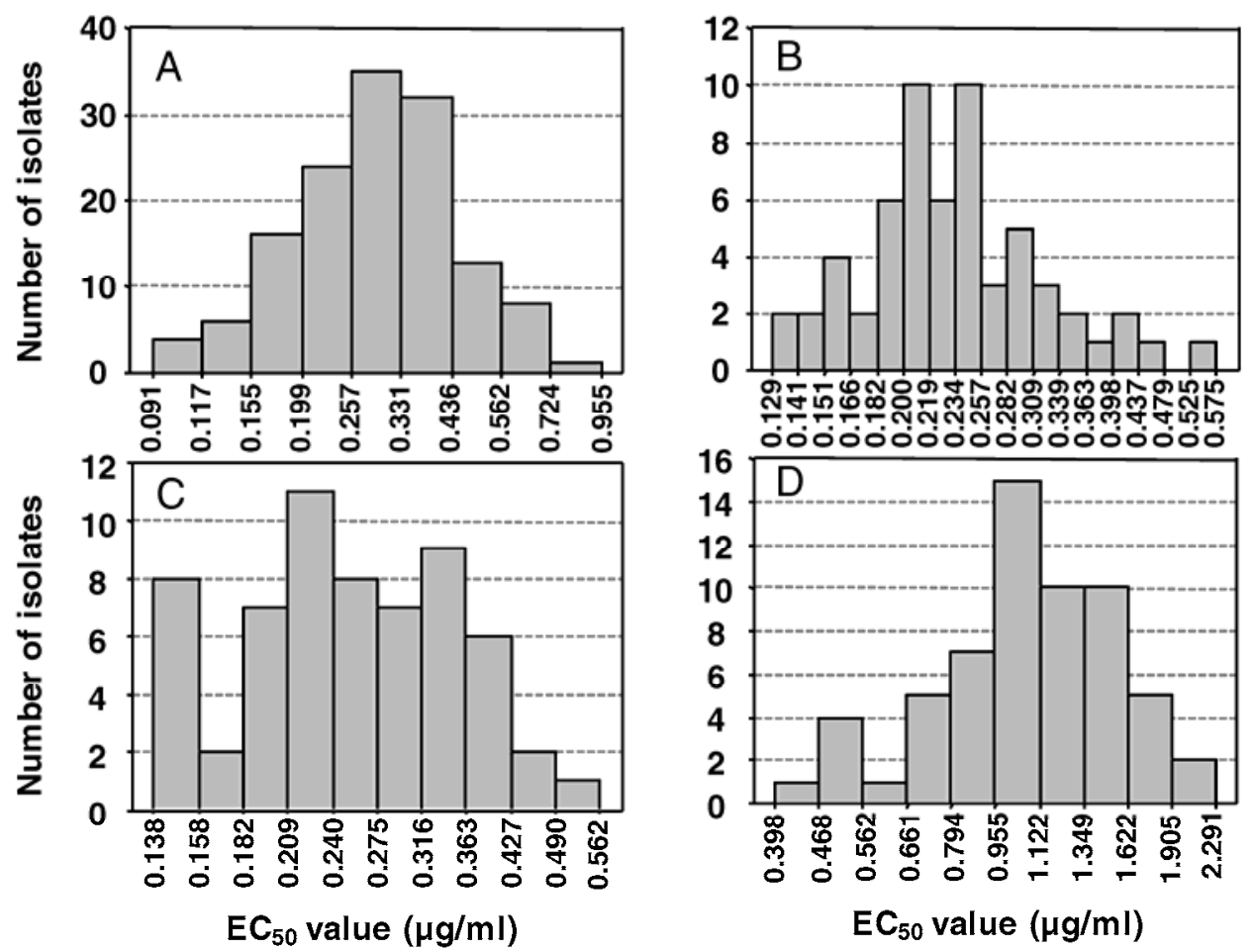

Fig. 1. Frequency histograms of effective concentrations $(\mu \mathrm{g} / \mathrm{ml})$ to inhibit mycelial growth of Galactomyces citri-aurantii by $50 \%$ ( $E C_{50}$ values) for $\mathbf{A}$, propiconazole $(n=139)$, B, metconazole $(n=60), \mathbf{C}$, cyproconazole $(n=60)$, and $\mathbf{D}$, tebuconazole $(n=60)$ as determined by the spiral gradient dilution method. Bar height indicates the total number of isolates within each bin, and bin width was based on Scott's method (41). 
normally distributed based on significant Shapiro-Wilk probability values $(P<0.05)$.

To evaluate the presence of cross-resistance between propiconazole and imazalil among 37 isolates of $P$. digitatum, $\log _{10}$-transformed $\mathrm{EC}_{50}$ values for propiconazole were regressed against those for imazalil. Two clusters of isolates were found in this regression (Fig. 4). One of the clusters consisted of isolates sensitive to the two fungicides, whereas the other cluster contained isolates with reduced sensitivities. The regression line had a coefficient of determination of $r^{2}=0.72$ (Fig. 4).

Effect of pH on activity of propiconazole against $G$. citri-aurantii and $\boldsymbol{P}$. digitatum. Growth of both fungi in nonamended PDB in microtiter plate wells that were inoculated with conidia was significantly higher $(P<0.05)$ at $\mathrm{pH} 5$ than at $\mathrm{pH} 3,7$, or 9 (Fig. 5). Growth of G. citri-aurantii was equally low at $\mathrm{pH} \mathrm{3,} \mathrm{7,} \mathrm{and} 9$ whereas, for $P$. digitatum, the lowest amount of mycelial production was observed at $\mathrm{pH} 9$. In propiconazole-amended media, both fungi were inhibited over the entire $\mathrm{pH}$ range tested compared with media not amended with the fungicide. Although, for both species, overall inhibition by propiconazole was highest at $\mathrm{pH} 9$ and growth was significantly $(P<0.05)$ reduced by propiconazole at each $\mathrm{pH}$ value, inhibition relative to the nonamended control was highest at pH 5 (Fig. 5).

Estimation of resistance frequencies against propiconazole in populations of $G$. citri-aurantii, $G$. geotrichum, and $P$. digitatum in laboratory selection studies. When conidial suspensions of 11 individual isolates of G. citri-aurantii were subjected to selection by propiconazole, colonies growing at propiconazole concentrations higher than the $\mathrm{EC}_{95}$ values were observed for two isolates (Gca 22 or AN4073 and Gca 83 or AN4129). These colonies grew at a propiconazole concentration range between 9.0 and $29.8 \mu \mathrm{g} / \mathrm{ml}$ on the selection plates (Table 5). For each of the two isolates, subcultures of six of these colonies grown on nonamended PDA were characterized for their fungicide sensitivity. With mean resistance factors of 0.97 and 0.98 , sensitivities were not significantly different from the original isolates (Table 5). When a mixture of conidia from the 11 isolates of G. citri-aurantii was subjected to selection, two colonies were found growing at the higher fungicide concentration range. After subculturing, both of these colonies showed an $\mathrm{EC}_{50}$ value within the propiconazole sensitivity range of all isolates evaluated for this species (data not shown) and, thus, were considered to be propiconazole-sensitive.

For G. geotrichum, a 10-fold lower concentration of conidia was applied to the selection plates than for G. citri-aurantii because numerous slow-growing colonies developed in the higher fungicide concentration range that could otherwise not be subcultured without cross-contamination. Among the 12 individual isolates subjected to propiconazole, putatively resistant colonies growing at propiconazole ranges between 2.96 and $9.75 \mu \mathrm{g} / \mathrm{ml}$ were obtained from 4 isolates (Table 6). Mean $\mathrm{EC}_{50}$ values for selected colonies from two isolates (Gg 6 or AN1562, six colonies; and Gg 30 or AN2552, five colonies) were not significantly different from the original isolates. Mean $\mathrm{EC}_{50}$ values for selected colonies from the other two isolates (Gg 75 or AN4227 and Gg 121 or AN1648, six colonies each), however, were significantly higher than for the original isolates (i.e., $0.09 \mu \mathrm{g} / \mathrm{ml}$ for $\mathrm{Gg} 75$ and $0.07 \mu \mathrm{g} / \mathrm{ml}$ for $\mathrm{Gg}$ 121 ), with a range of 0.11 to $0.21 \mu \mathrm{g} / \mathrm{ml}$ for colonies recovered for isolate $\mathrm{Gg} 75$ and 0.13 to $0.16 \mu \mathrm{g} / \mathrm{ml}$ for colonies for isolate $\mathrm{Gg}$ 121 (data not shown). Still, resistance factors only ranged from 1.3 to 2.3 with means of 1.71 and 1.97 for isolates $\mathrm{Gg} 75$ and $\mathrm{Gg} 121$, respectively (Table 6).

For $P$. digitatum, laboratory selections were done using conidial suspensions from isolates sensitive and less sensitive to propiconazole. Of the total of 12 isolates used, colonies growing at concentrations of propiconazole $>\mathrm{EC}_{95}$ were identified for 5 sensitive isolates and for 4 less-sensitive isolates. For the selections from sensitive isolates, $\mathrm{EC}_{50}$ values were determined for a total of six colonies after subculturing on nonamended PDA. All isolates had significantly higher $\mathrm{EC}_{50}$ values $(0.20$ to $0.45 \mu \mathrm{g} / \mathrm{ml}$, mean 0.35 $\mu \mathrm{g} / \mathrm{ml}$ ) than the original isolates ( 0.006 to $0.010 \mu \mathrm{g} / \mathrm{ml}$, mean 0.007 $\mu \mathrm{g} / \mathrm{ml}$ ) (Table 7). Resistance factors ranged from 14.3 to 81.6 (mean 41.3) and resistance frequencies ranged from $8.0 \times 10^{-8}$ to
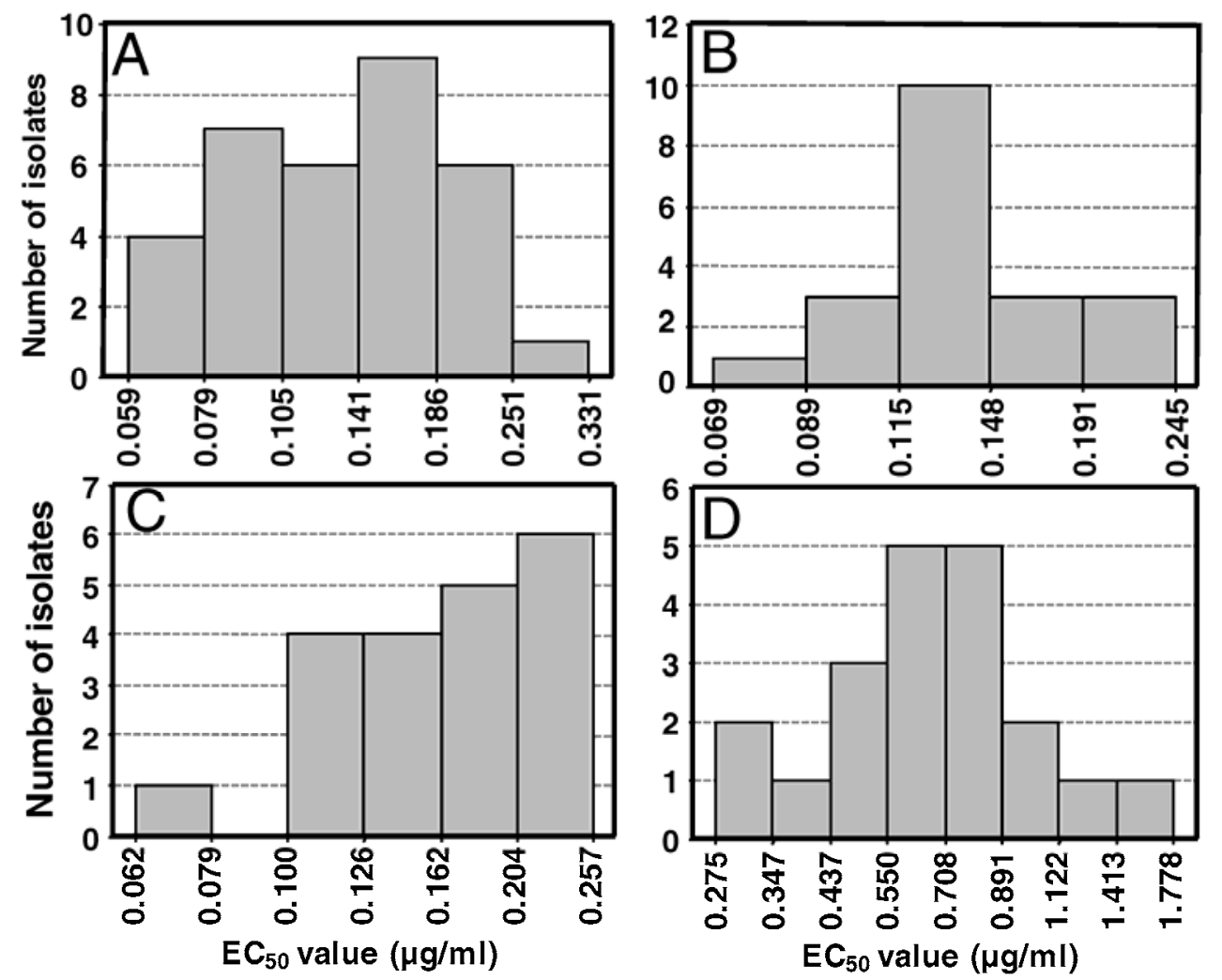

Fig. 2. Frequency histograms of effective concentrations $(\mu \mathrm{g} / \mathrm{ml})$ to inhibit mycelial growth of Galactomyces geotrichum by $50 \%$ (EC 50 values) for $\mathbf{A}$, propiconazole $(n=33)$, B, metconazole $(n=20), \mathbf{C}$, cyproconazole $(n=20)$, and $\mathbf{D}$, tebuconazole $(n=20)$ as determined by the spiral gradient dilution method. Bar height indicates the total number of isolates within each bin, and bin width was based on Scott's method (41). 
$1.2 \times 10^{-7}$. For the selections from less-sensitive isolates, $\mathrm{EC}_{50}$ values for a total of six subcultured colonies also were significantly higher $(1.29$ to $2.88 \mu \mathrm{g} / \mathrm{ml}$, mean $2.06 \mu \mathrm{g} / \mathrm{ml})$ than the original isolates ( 0.33 to $0.63 \mu \mathrm{g} / \mathrm{ml}$, mean $0.45 \mu \mathrm{g} / \mathrm{ml}$ ) (Table 7). Resistance factors ranged from 2.3 to 7.9 with a mean of 5.1 and resistance frequencies ranged from $8 \times 10^{-8}$ to $1.6 \times 10^{-7}$.

Estimation of natural resistance frequencies to propiconazole in populations of $\boldsymbol{G}$. citri-aurantii from lemon grove soils. In repeated experiments, 6 to 10 colonies per plate were observed growing at propiconazole concentrations $>\mathrm{EC}_{95}$. These colonies were very slow growing, and four to six colonies per plate were subcultured. When tested for propiconazole sensitivity, $\mathrm{EC}_{50}$ values of none of these colonies were significantly higher than the highest value (i.e., $0.83 \mu \mathrm{g} / \mathrm{ml}$ ) found among all isolates of the species.

\section{Discussion}

This research presents in vitro sensitivities of the two sour rot pathogens $G$. citri-aurantii and G. geotrichum against the DMItriazoles propiconazole, cyproconazole, metconazole, and tebuconazole; sensitivities against additional DMI-triazoles and registered postharvest fungicides for G. citri-aurantii; and a sensitivity range for $P$. digitatum against propiconazole. Our primary focus was on the sour rot pathogens of tree fruit and the specific needs of the citrus and stone fruit industries to identify and register a highly effective fungicide to manage this decay. This need was supported

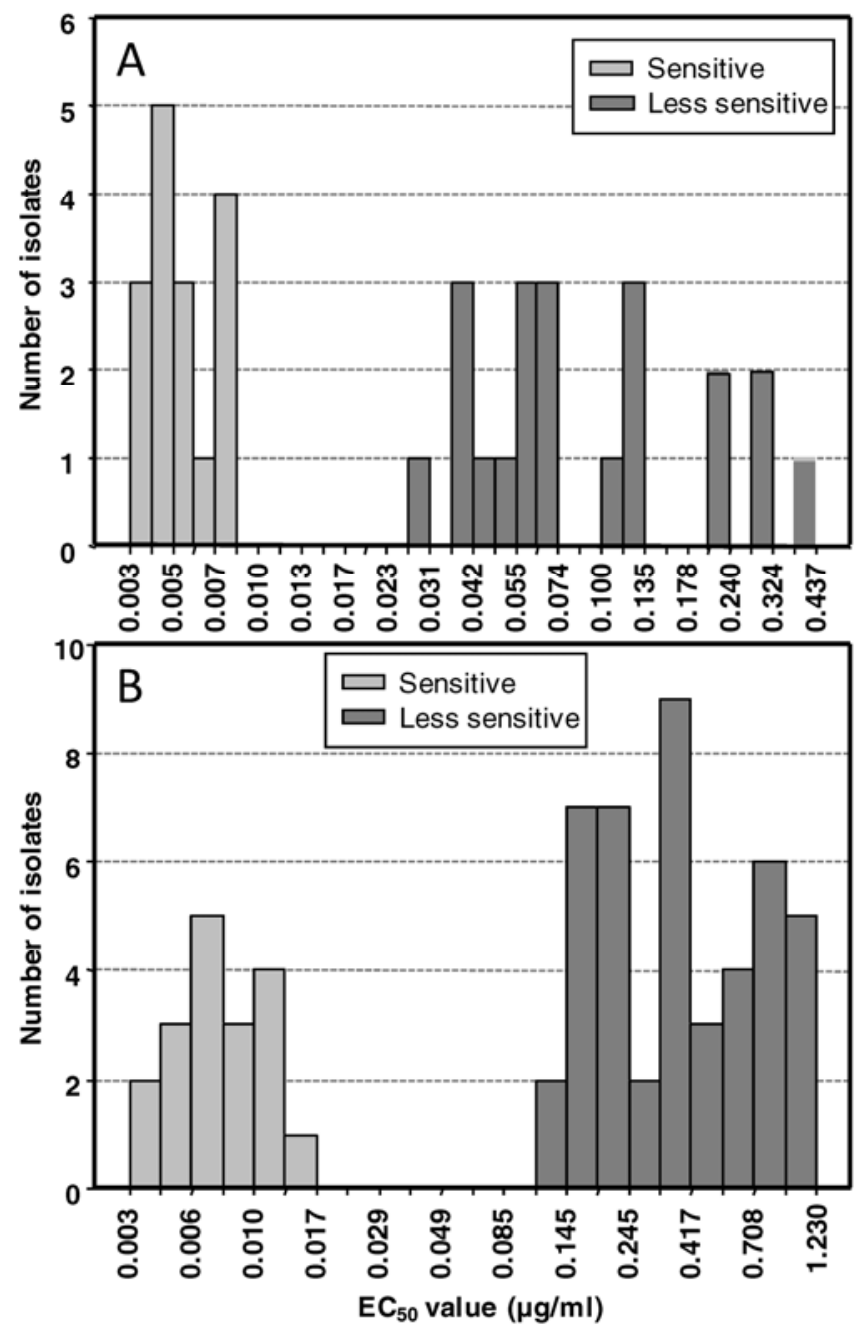

Fig. 3. Frequency histograms of effective concentrations $(\mu \mathrm{g} / \mathrm{ml})$ to inhibit growth of Penicillium digitatum by $50 \%$ ( $\mathrm{EC}_{50}$ values) for $\mathbf{A}$, imazalil (37 isolates) or $\mathbf{B}$, propiconazole (63 isolates). Isolates were designated as sensitive or less sensitive to the two fungicides based on $\mathrm{EC}_{50}$ values as determined by the spiral gradient dilution method. Bin height indicates the total number of isolates within each bin, and bin width was based on Scott's method (41). by our findings that none of the currently registered citrus postharvest fungicides, with the exception of SOPP, or stone fruit postharvest fungicides is effective against sour rot. Additionally, an emphasis was placed on propiconazole because of its effectiveness against Galactomyces spp., as well as support (i.e., allowing registration for this use) from the registrant and regulatory agencies for introduction on these crops for postharvest use. The green mold pathogen of citrus, $P$. digitatum, was included due to its central role in citrus postharvest decay management, its history of fungicide resistance development $(20,27)$, and because a



Fig. 4. Scatter plot and linear regression of effective concentrations to inhibit mycelial growth by $50 \%$ ( $\mathrm{EC}_{50}$ values) for propiconazole plotted against those for imazalil (both demethylation-inhibiting [DMI] fungicides). Filled and open circles designate DMI-sensitive and less-sensitive strains, respectively, among the total of 37 isolates of Penicillium digitatum evaluated.

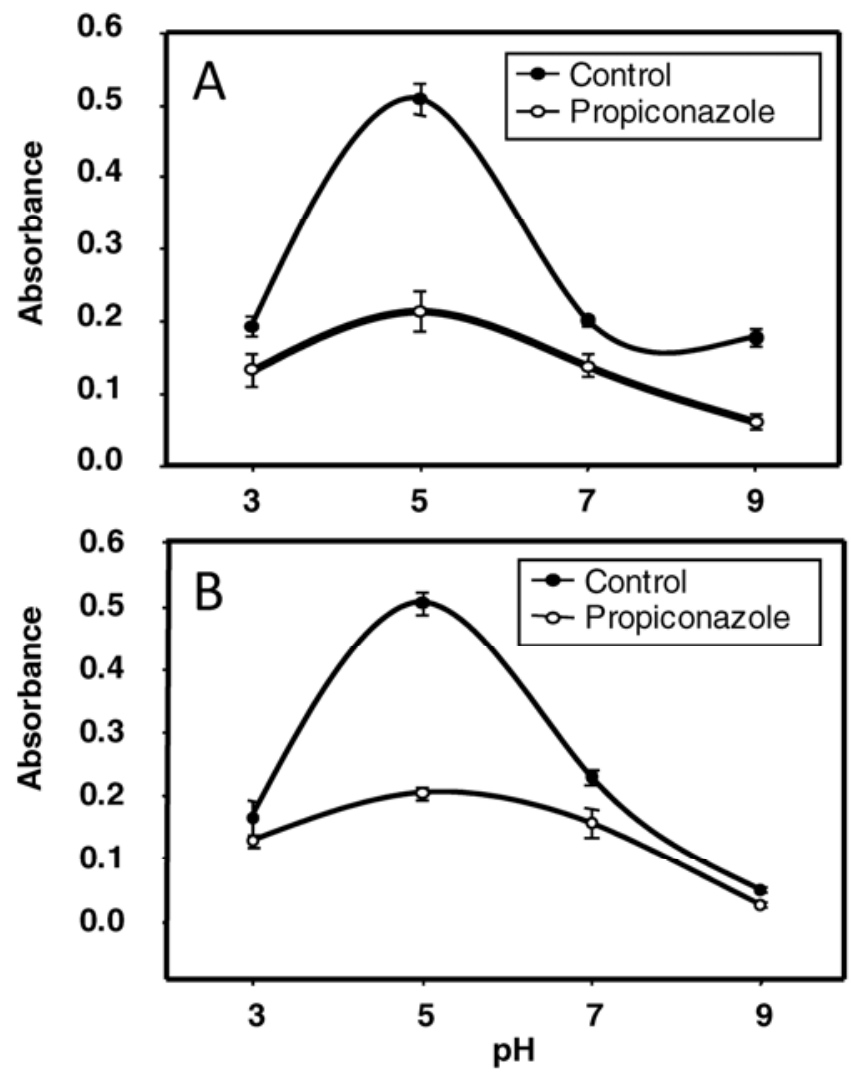

Fig. 5. Mycelial growth of A, Galactomyces citri-aurantii after $18 \mathrm{~h}$ and $\mathbf{B}$, Penicillium digitatum after $24 \mathrm{~h}$ of incubation at $25^{\circ} \mathrm{C}$ as measured by absorbance at $490 \mathrm{~nm}$ in microtiter plate assays. Potato dextrose broth was amended or not amended with propiconazole and adjusted to selected $\mathrm{pH}$ values. 
DMI-imidazole fungicide is already registered on citrus for its management.

The baseline sensitivity of a fungicide is the sensitivity range of a fungal population before the introduction of the specific fungicide (39). None of the DMI-triazole fungicides evaluated have ever been used commercially by the California citrus industry and, thus, isolates of $G$. citri-aurantii and $P$. digitatum have not been exposed to these fungicides. Still, the sensitivity ranges we are presenting may perhaps not be called baseline sensitivities. This is because the DMI-imidazole imazalil has been in use for many years, specifically for control of Penicillium decays. Cross-resistance between the two DMI subclasses is well documented (32) and was also demonstrated in our study for $P$. digitatum (see below). For G. geotrichum, many of the isolates included in our study were collected before the introduction of DMI fungicides and, thus, for this species, the sensitivity ranges presented are described as baseline sensitivities.

A wide range of effective concentrations to inhibit growth of $G$. citri-aurantii by $50 \%$ was obtained for the eight DMI-triazole fungicides evaluated. In comparisons of the most effective fungicides (i.e., cyproconazole, propiconazole, metconazole, and tebuconazole), mean $50 \%$ inhibitory concentrations were all lower for G. geotrichum than for G. citri-aurantii. For both species, however, inhibitory concentrations were similar for cyproconazole, propiconazole, and metconazole and higher for tebuconazole. All DMI

Table 5. Characteristics of isolates of Galactomyces citri-aurantii recovered from propiconazole-amended selection plates ${ }^{\mathrm{u}}$

\begin{tabular}{|c|c|c|c|c|c|}
\hline $\begin{array}{l}\text { Original } \\
\text { isolate }^{v}\end{array}$ & $\begin{array}{l}\mathrm{EC}_{50} \text { value of original } \\
\text { isolate }(\mu \mathrm{g} / \mathrm{ml})^{\mathrm{w}}\end{array}$ & $\begin{array}{l}\text { Range of propiconazole concentrations } \\
(\mu \mathrm{g} / \mathrm{ml}) \text { used for colony selection }{ }^{\mathrm{x}}\end{array}$ & $\begin{array}{l}\text { Number of } \\
\text { recovered colonies }\end{array}$ & $\begin{array}{c}\text { Mean } \mathrm{EC}_{50} \text { value of } \\
\text { recovered colonies }(\mu \mathrm{g} / \mathrm{ml})^{\mathrm{y}}\end{array}$ & $\begin{array}{l}\text { Mean resistance } \\
\text { factor }^{\mathrm{z}}\end{array}$ \\
\hline Gca 22 & $0.64 \mathrm{Aa}$ & $16.4-33.6$ & 6 & $0.62 \mathrm{Aa}$ & $0.98 \mathrm{~A}$ \\
\hline Gca 83 & $0.61 \mathrm{Aa}$ & $9.0-29.8$ & 6 & $0.59 \mathrm{Aa}$ & $0.97 \mathrm{~A}$ \\
\hline Mean & $0.62 \mathrm{a}$ & $\ldots$ & $\ldots$ & $0.61 \mathrm{a}$ & $\ldots$ \\
\hline
\end{tabular}

"Values followed by the same letter are not significantly different $(P<0.01)$ following an analysis of variance and least significant difference mean separation procedures. Uppercase letters are for comparisons between isolates (columns), whereas lowercase letters are for comparisons within rows.

${ }^{v}$ Original isolates $\left(5 \times 10^{8}\right.$ conidia/ml) were evenly spread onto propiconazole-amended potato dextrose agar (PDA) plates using a spiral plater (see Materials and Methods).

${ }^{\mathrm{w}}$ Effective concentration for $50 \%$ reduction of mycelial growth $\left(\mathrm{EC}_{50}\right)$ values were determined using the spiral gradient dilution method.

${ }^{\mathrm{x}}$ Range of propiconazole concentrations on the selection plates where putatively resistant isolates were recovered.

${ }^{\mathrm{y}}$ Mean $\mathrm{EC}_{50}$ values of selected colonies after subculturing on nonamended PDA.

${ }^{\mathrm{z}}$ Mean resistance factor of selected colonies based on the ratio of $\mathrm{EC}_{50}$ values of recovered isolates to original isolates.

Table 6. Characteristics of isolates of Galactomyces geotrichum recovered from propiconazole-amended selection plates ${ }^{\mathrm{u}}$

\begin{tabular}{|c|c|c|c|c|c|}
\hline $\begin{array}{l}\text { Original } \\
\text { isolate }^{v}\end{array}$ & $\begin{array}{l}\mathrm{EC}_{50} \text { value of original } \\
\text { isolate }(\mu \mathrm{g} / \mathrm{ml})^{\mathrm{w}}\end{array}$ & $\begin{array}{l}\text { Range of propiconazole concentrations } \\
(\mu \mathrm{g} / \mathrm{ml}) \text { used for colony selection }\end{array}$ & $\begin{array}{c}\text { Number of } \\
\text { recovered colonies }\end{array}$ & $\begin{array}{c}\text { Mean } \mathrm{EC}_{50} \text { value of } \\
\text { recovered colonies }(\mu \mathrm{g} / \mathrm{ml})^{\mathrm{y}}\end{array}$ & $\begin{array}{l}\text { Mean resistance } \\
\text { factor }^{\mathrm{z}}\end{array}$ \\
\hline Gg 6 & $0.15 \mathrm{Aa}$ & $7.68-9.75$ & 6 & $0.14 \mathrm{Aa}$ & $0.98 \mathrm{~A}$ \\
\hline Gg 30 & $0.21 \mathrm{Aa}$ & $7.68-9.75$ & 5 & $0.21 \mathrm{Aa}$ & $0.98 \mathrm{~A}$ \\
\hline $\mathrm{Gg} 75$ & $0.09 \mathrm{Bb}$ & $6.06-9.75$ & 6 & $0.15 \mathrm{Aa}$ & $1.71 \mathrm{~B}$ \\
\hline Gg 121 & $0.07 \mathrm{Bb}$ & $2.96-9.75$ & 6 & $0.14 \mathrm{Aa}$ & $1.97 \mathrm{~B}$ \\
\hline Mean & $0.13 \mathrm{~b}$ & $\ldots$ & $\ldots$ & $0.16 \mathrm{a}$ & $\ldots$ \\
\hline
\end{tabular}

"Values followed by the same letter are not significantly different $(P<0.01)$ following an analysis of variance or general linear model and least significant difference mean separation procedures. Uppercase letters are for comparisons between isolates (columns), whereas lowercase letters are for comparisons within rows.

${ }^{\mathrm{v}}$ Original isolates $\left(5 \times 10^{7}\right.$ conidia/ml) were evenly spread onto propiconazole-amended potato dextrose agar (PDA) plates using a spiral plater (see Materials and Methods).

${ }^{w}$ Effective concentration for $50 \%$ reduction of mycelial growth $\left(\mathrm{EC}_{50}\right)$ values were determined using the spiral gradient dilution method.

${ }^{x}$ Range of propiconazole concentrations on the selection plates where putatively resistant isolates were recovered.

${ }^{\mathrm{y}}$ Mean $\mathrm{EC}_{50}$ values of selected colonies after subculturing on nonamended PDA.

${ }^{\mathrm{z}}$ Mean resistance factor of selected colonies based on the ratio of $\mathrm{EC}_{50}$ values of recovered isolates to original isolates.

Table 7. Characteristics of isolates of Penicillium digitatum recovered from propiconazole-amended selection plates ${ }^{\mathrm{u}}$

\begin{tabular}{|c|c|c|c|c|c|c|}
\hline $\begin{array}{l}\text { Original } \\
\text { isolate }^{v}\end{array}$ & $\begin{array}{l}\mathrm{EC}_{50} \text { value of original } \\
\text { isolate }(\mu \mathrm{g} / \mathrm{ml})^{\mathrm{w}}\end{array}$ & $\begin{array}{l}\text { Propiconazole concentrations }(\mu \mathrm{g} / \mathrm{ml}) \\
\text { used for colony selection }^{\mathrm{x}}\end{array}$ & $\begin{array}{l}\text { Number of } \\
\text { recovered colonies }\end{array}$ & $\begin{array}{c}\text { Mean } \mathrm{EC}_{50} \text { value of } \\
\text { recovered colonies }(\mu \mathrm{g} / \mathrm{ml})^{\mathrm{y}}\end{array}$ & $\begin{array}{l}\text { Resistance } \\
\text { factor }^{\mathrm{Z}}\end{array}$ & Mean \\
\hline Pd 3117-S & 0.008 & 0.48 & 1 & 0.45 & 64.3 & $41.3 \mathrm{a}$ \\
\hline Pd 3140-S & 0.008 & 0.34 & 1 & 0.33 & 27.7 & $\ldots$ \\
\hline Pd 3177-S & 0.010 & 0.27 & 1 & 0.24 & 18.4 & $\ldots$ \\
\hline Pd 3180-S & 0.006 & 0.19 & 1 & 0.20 & 14.3 & $\ldots$ \\
\hline Pd 3185-S & 0.006 & $0.43,0.54$ & 2 & 0.44 & 81.6 & $\ldots$ \\
\hline Mean & $0.007 \mathrm{Bb}$ & $\ldots$ & $\ldots$ & $0.35 \mathrm{Ba}$ & $\ldots$ & $\ldots$ \\
\hline Pd 3113-R & 0.47 & 51.3 & 1 & 1.29 & 2.8 & $5.1 \mathrm{~b}$ \\
\hline Pd 3121-R & 0.36 & $54.4,57.8$ & 2 & 2.88 & 7.9 & $\ldots$ \\
\hline Pd 3122-R & 0.33 & 48.4 & 1 & 2.47 & 7.4 & $\ldots$ \\
\hline $\mathrm{Pd} 3128-\mathrm{R}$ & 0.63 & $43.0,45.6$ & 2 & 1.41 & 2.3 & $\ldots$ \\
\hline Mean & $0.45 \mathrm{Ab}$ & $\ldots$ & $\ldots$ & $2.06 \mathrm{Aa}$ & $\ldots$ & $\ldots$ \\
\hline
\end{tabular}

u Values followed by the same letter are not significantly different $(P<0.01)$ following an analysis of variance or general linear model and least significant difference mean separation procedures. Uppercase letters are for comparisons between isolates (columns), whereas lowercase letters are for comparisons within rows.

${ }^{\vee}$ Original isolates $\left(10^{8}\right.$ conidia/ml) were evenly spread onto propiconazole-amended potato dextrose agar (PDA) plates using a spiral plater (see Materials and Methods). Isolate designations: $\mathrm{S}=$ sensitive and $\mathrm{R}=$ reduced sensitivity to propiconazole. Isolate numbers refer to accession numbers.

${ }^{\mathrm{w}}$ Effective concentration for $50 \%$ reduction of mycelial growth $\left(\mathrm{EC}_{50}\right)$ values were determined using the spiral gradient dilution method.

${ }^{x}$ Propiconazole concentrations on the selection plates where putatively resistant isolates were recovered.

${ }^{\mathrm{y}}$ Mean $\mathrm{EC}_{50}$ values of selected colonies after subculturing on nonamended PDA.

${ }^{\mathrm{z}}$ Mean resistance factor of selected colonies based on the ratio of $\mathrm{EC}_{50}$ values of recovered isolates to original isolates. 
fungicides inhibit demethylation at position 14 of lanosterol or 24methylene dihydrolanosterol, which are precursors of sterols in fungi $(32,40)$. Differences in sensitivity among DMI compounds have been observed for other plant-pathogenic fungi (31) and can be explained by different affinities for the triazole-binding site on the cytochrome P450 isoenzyme 51 (CYP51/lanosterol-14 $\alpha$-demethylase) (38). For $P$. digitatum, we determined that isolates were cross-resistant for propiconazole and the DMI-imidazole imazalil. Resistance to triazole and imidazole fungicides has been correlated with mutations in the gene encoding CYP51 in several fungi, including Mycosphaerella fijiensis (10) and P. digitatum (23). However, for the isolates with reduced sensitivity in our study, there was no clear correlation between the degrees of insensitivity to the two DMI subclasses. Differences in binding sites for the fungicides again could be responsible for this lack of correlation. Therefore, it is possible that propiconazole may be partially effective against decay caused by imazalil-resistant populations of $P$. digitatum that commonly occur in California packinghouses. Still, use of propiconazole after registration is recommended only as a mixture with a fungicide of a different class (i.e., azoxystrobin, fludioxonil, pyrimethanil, or possibly thiabendazole) to avoid exacerbation of the widespread DMI resistance.

For G. citri-aurantii, we used 139 isolates in the sensitivity tests for propiconazole. Based on the formula described by Leung et al. (34) of $N=\log (1-P) / \log (1-F)$, where $N$ is the sample size of the population and $P$ is the probability of detecting an outlier at frequency $F$ in the population, $97.8 \%$ of all $G$. citri-aurantii isolates will have $\mathrm{EC}_{50}$ values for inhibition of mycelial growth by propiconazole within the range we have described at a 95\% confidence level. Using this estimation method for G. geotrichum with 20 isolates evaluated, $91.3 \%$ of all isolates will have $\mathrm{EC}_{50}$ values within the described range. However, because isolates were of worldwide origin and soil samples were obtained from a variety of agricultural systems, the sensitivity range that we determined for this latter species is probably close to the actual range that would be based on a larger collection of isolates.

We found that growth of both citrus pathogens, G. citri-aurantii

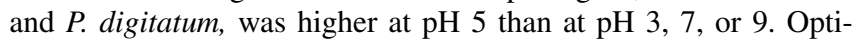
mum growth of $P$. digitatum was previously reported in the low $\mathrm{pH}$ range and, for G. citri-aurantii, an optimum of $\mathrm{pH} 6$ was determined $(19,46)$. Thus, these fungi are adapted to the acidic environment of citrus fruit. Depending on the level of fruit maturity, the $\mathrm{pH}$ of lemon albedo and flavedo has been determined as between 5.1 and $5.6(45)$.

Inhibition of growth of $G$. citri-aurantii and $P$. digitatum by propiconazole was highest at $\mathrm{pH} 5$ compared with the controls grown at the same $\mathrm{pH}$ without the fungicide. However, growth was significantly reduced in the presence of propiconazole over the entire $\mathrm{pH}$ range evaluated. This is important because postharvest fungicides are applied over a wide range of $\mathrm{pH}$ conditions, depending on whether the treatment is applied in water or in a fruit coating. Additionally, the fruit surface and juices diffusing from wounds can modify the $\mathrm{pH}$ in the micro-environment. Its activity over a wide $\mathrm{pH}$ range is one characteristic that can make propiconazole a reliable treatment for postharvest use. In similar studies by others, pyrimethanil, another postharvest citrus fungicide, was effective against conidial germination of $P$. digitatum over a wide range of $\mathrm{pH}$ conditions (43). In contrast, for imazalil, conidial germination of $P$. digitatum was most effectively reduced at $\mathrm{pH}$ values above 7 whereas, at values of lower than 5, germination was much less affected (45). A higher efficacy of imazalil at more basic $\mathrm{pH}$ conditions was also shown for $P$. italicum and the reduced activity at lower $\mathrm{pH}$ values was ascribed to decreased uptake of the fungicide by the mycelium of the fungus as a result of changes in electric charge of the molecule (42). In contrast, propiconazole has a pKa of 1.09 and is hydrolytically stable over a $\mathrm{pH}$ range of 1 to 13 (47). Thus, charge and uptake of the molecule by mycelium is unlikely to be affected by $\mathrm{pH}$.

In laboratory selections, isolates of $P$. digitatum with reduced sensitivity against propiconazole were obtained in mass platings of conidia from several single-spored propiconazole-sensitive isolates onto selective media. Resistance factors with a maximum of 81.6 were calculated for the recovered isolates. When isolates less sensitive to propiconazole $\left(\mathrm{EC}_{50}\right.$ values of 0.33 to $0.63 \mu \mathrm{g} / \mathrm{ml}$ ) were plated onto propiconazole-amended media, resistance factors of the recovered isolates ranged from 2.3 to 7.9 . We only evaluated a total of 12 colonies growing in the high-concentration range of propiconazole and, thus, these data may be biased. Still, these differences in resistance factors could be explained by the quantitative type of resistance to DMI fungicides where mutations accumulate step-wise and multiple selection processes have to occur to reach high levels of resistance. Because of the large difference in resistance factors observed when using conidia from sensitive (mean resistant factor $=41.3$ ) compared with less-sensitive isolates that were previously selected for in the commercial environment (mean resistant factor $=5.1$ ), there does not seem to be a linear relationship between increase in insensitivity and number of selection processes. Additionally, resistance frequencies in our selection studies ranged from $8.0 \times 10^{-8}$ to $1.6 \times 10^{-7}$ and, thus, were similar as for fludioxonil, where resistance frequencies from $9.7 \times 10^{-8}$ to $1.3 \times 10^{-7}$ were obtained previously in mass platings of mixed conidial suspensions from isolates of $P$. digitatum to selective media (30). In contrast, in this latter study, resistance frequencies for pyrimethanil were significantly higher and ranged from $6.9 \times 10^{-5}$ to $1.1 \times 10^{-4}$.

No isolates with stable reduced sensitivity to propiconazole were recovered for $G$. citri-aurantii in these studies using conidial suspensions from single isolates or in soil population enrichment assays. In these latter tests, diverse populations were sampled from citrus groves where genetic variability from various selection processes and sexual recombination could have occurred. The propiconazole sensitivity range for the 139 isolates from diverse origins evaluated was rather narrow, with a factor of less than 10. Apparently, although G. citri-aurantii populations have been exposed to the DMI imazalil for many years, selection for DMI resistance has not occurred, possibly because the imidazole imazalil is not very active against this pathogen and the fungicide is only used in the packinghouse. For other fungi, a wide range in baseline sensitivities has been attributed to an increased risk of resistance development due to directional selection toward less-sensitive biotypes with repeated fungicide applications (33).

For G. geotrichum, mean resistance factors obtained in selections using two of the isolates were between 1.71 and 1.97 and $\mathrm{EC}_{50}$ values were within the sensitivity range of the worldwide collection of 33 isolates. Compared with the moderately resistant isolates selected from sensitive isolates of $P$. digitatum where a mean resistance factor of 41.3 was found, resistance factors for $G$. geotrichum were relatively low. Therefore, our data indicate that species of Galactomyces may have an intrinsically lower risk for resistance development to DMI fungicides. Natural resistance frequencies and the risk of resistance development are dependent on the organism being exposed and the selection agent. Biological as well as genetic characteristics of a pathogen may determine the risk. Thus, for Penicillium spp., the high reproductive potential and heterokaryosis have been attributed to the increased risk of resistance development (30). As indicated above, differences in resistance frequencies among fungicides have been previously reported for $P$. digitatum with higher frequencies for pyrimethanil compared with fludioxonil, whereas no resistant isolates were recovered for azoxystrobin (30). Similarly, in laboratory studies using mass platings of single-spore isolates of the pome fruit pathogen $P$. expansum, stable resistant isolates were readily obtained for fludioxonil and pyrimethanil but not for the DMI fungicide difenoconazole (1).

The establishment of sensitivity ranges in pathogen populations before the commercial introduction of a new fungicide has become an essential component in the implementation of anti-resistance strategies $(5,6)$. By routine monitoring for changes in sensitivity in the target populations, rotations and mixtures between different chemical classes effective against the specific pathogen can be utilized before resistant populations cause crop losses. Multiple 
alternatives are available for the management of Penicillium decays to apply these strategies. For sour rot, however, propiconazole will be the only highly effective treatment in the United States and it is essential that its efficacy is maintained until, eventually, new treatments become available. Although our studies indicate that a lower risk for resistance development potentially exists for $\mathrm{Ga}$ lactomyces spp. against DMI fungicides, microorganisms, with their often immense reproductive potential, have the capacity to adapt to their changing environment by different means.

\section{Acknowledgments}

We thank K. Ko for technical assistance and the California Citrus Research Board for financial support of this research.

\section{Literature Cited}

1. Adaskaveg, J., and Förster, H. 2010. Selection of isolates of Penicillium expansum with reduced sensitivity to fludioxonil and pyrimethanil from sensitive, single-spored isolates. (Abstr.) Phytopathology 100:S2.

2. Adaskaveg, J. E., Förster, H., Driever, G., and Crisosto, C. 2007. Update on Mentor 45WP-a "new tool" for postharvest management of sour rot of stone fruit in the 2007 season. Online publication. http://www2.uckac.edu/ postharv/new-CVPN.htm.

3. Baudoin, A. B. A. M., and Eckert, J. W. 1982. Factors influencing the susceptibility of lemons to infection by Geotrichum candidum. Phytopathology 72:1592-1597.

4. Baudoin, A. B. A. M., and Eckert, J. W. 1985. Development of resistance against Geotrichum candidum in lemon peel injuries. Phytopathology 75:174-179.

5. Brent, K. J. 1988. Monitoring for fungicide resistance. Pages 9-11 in: Fungicide Resistance in North America. C. J. Delp, ed. American Phytopathological Society, St. Paul, MN.

6. Brent, K. J., and Holloman, D. W. 2007. Fungicide resistance: the assessment of risk. In: FRAC Monogr. No. 2, second edition. Fungicide Resistance Action Committee, United Kingdom.

7. Brown, G. E. 1979. Biology and control of Geotrichum candidum the cause of citrus sour rot. Proc. Fla. State Hortic. Soc. 92:186-189.

8. Butler, E. E., Fogle, D., and Miranda, M. 1988. Galactomyces citri-aurantii a newly found teleomorph of Geotrichum citri-aurantii the cause of sour rot of citrus fruit. Mycotaxon 33:197-212.

9. Butler, E. E., and Petersen, L. J. 1972. Endomyces geotrichum a perfect state of Geotrichum candidum. Mycologia 64:365-374.

10. Cañas-Gutiérrez, G. P., Angarita-Velásquez, M. J., Restrepo-Flórez, J. M., Rodríguez, P., Moreno, C. X., and Arango, R. 2009. Analysis of the CYP51 gene and encoded protein in propiconazole-resistant isolates of Mycosphaerella fijiensis. Pest Manage. Sci. 65:892-899.

11. Cochran, A., Adaskaveg, J. E., and Förster, H. 2009. Propiconazole and fludioxonil for managing postharvest fungal decays of fresh market tomato. (Abstr.) Phytopathology 99:S23.

12. Davis, L. L., and Baudoin, A. B. A. M. 1986. Effect of osmotic potential on Geotrichum candidum growth, polygalacturonase production and polygalacturonase action. Physiol. Mol. Plant Pathol. 28:53-60.

13. de Waard, M. A., and Fuchs, A. 1982. Resistance to ergosterol-biosynthesis inhibitors II. Genetic and physiological aspects. Pages 87-99 in: Fungicide Resistance in Crop Protection. J. Dekker and S. G. Georgopoulos, eds. Centre for Agricultural Publication and Documentation, Wageningen, The Netherlands.

14. de Waard, M. A., and Van Nistelrooy, J. G. M. 1990. Stepwise development of laboratory resistance to DMI-fungicides in Penicillium italicum. Neth. J. Plant Pathol. 96:321-329.

15. Domsch, K. H., Gams, W., and Anderson, T.-H. 1993. Compendium of Soil Fungi, Vol. 1. IHW-Verlag, Eching, Germany.

16. Eckert, J. W. 1959. Lemon sour rot. Calif. Citrogr. 45:30-36.

17. Eckert, J. W. 1988. Resistance of Penicillium digitatum to imazalil treatments in California packinghouses. ISPP Chem. Control Newsl. 10:36-38.

18. Eckert, J. W., and Butler, E. E. 1962. A sensitive method for the isolation of Geotrichum candidum from soil. Mycologia 54:106-109.

19. Eckert, J. W., and Eaks, I. L. 1989. Postharvest disorders and diseases of citrus fruits. Pages 179-260 in: The Citrus Industry: Volume V. W. Reuther, C. E. Calavan, and G. E. Carmen, eds. University of California, Division of Agriculture and Natural Resources, Oakland.

20. Eckert, J. W., and Wild, B. L. 1983. Problems of fungicide resistance in Penicillium rot of citrus fruit. Pages 525-556 in: Pest Resistance to Pesticides. G. P. Georghiou and T. Saito, eds. Plenum Publishing Corp., New York.

21. Förster, H., Kanetis, L., and Adaskaveg, J. E. 2004. Spiral gradient dilution, a rapid method for determining growth responses and $50 \%$ effective concentration values in fungus-fungicide interactions. Phytopathology 94:163-170.
22. Georgopoulos, S. G. 1982. Detection and measurement of fungicide resistance. Pages 24-31 in: Fungicide Resistance in Crop Protection. J. Dekker and S. G. Georgopoulos, eds. Centre for Agricultural Publishing and Documentation, Wageningen, The Netherlands.

23. Hamamoto, H., Hasegawa, K., Nakaune, R., Lee Y. J., Makizumi, Y., Akutsu, K., and Hibi, T. 2000. Tandem repeat of a transcriptional enhancer upstream of the sterol 14 $\alpha$-demethylase gene (CYP51) in Penicillium digitatum. Appl. Environ. Microbiol. 66:3421-3426.

24. Harding, P. R. 1962. Differential sensitivity to sodium ortho-phenylphenate by biphenyl-sensitive and bi-phenyl-resistant strains of Penicillium digitatum. Plant Dis. Rep. 46:100-104.

25. Harding, P. R. 1972. Differential sensitivity to thiabendazole by strains of Penicillium italicum and P. digitatum. Plant Dis. Rep. 56:256-260.

26. Hershenhorn, J., Dori, S., and Barash, I. 1992. Association of Geotrichum citri-aurantii with citrus groves in Israel. Phytoparasitica 20:31-36.

27. Holmes, G. J., and Eckert, J. W. 1999. Sensitivity of Penicillium digitatum and $P$. italicum to postharvest citrus fungicides in California. Phytopathology 89:716-721.

28. Kanetis, L., Förster, H., and Adaskaveg, J. E. 2007. Comparative efficacy of the new postharvest fungicides azoxystrobin, fludioxonil, and pyrimethanil for managing citrus green mold. Plant Dis. 91:1502-1511.

29. Kanetis, L., Förster, H., and Adaskaveg, J. E. 2008. Baseline sensitivities for new postharvest fungicides against Penicillium spp. on citrus and multiple resistance evaluations in $P$. digitatum. Plant Dis. 92:301-310.

30. Kanetis, L., Förster, H., and Adaskaveg, J. E. 2010. Determination of natural resistance frequencies in Penicillium digitatum using a new air-sampling method and characterization of fludioxonil- and pyrimethanil-resistant isolates. Phytopathology 100:738-746.

31. Karaoglanidis, G. S., and Thanassoulopoulos, C. C. 2003. Cross-resistance patterns among sterol biosynthesis inhibiting fungicides (SBIs) in Cercospora beticola. Eur. J. Plant Pathol. 109:929-934.

32. Köller, W. 1988. Sterol demethylation inhibitors: mechanism of action and resistance. Pages 79-88 in: Fungicide Resistance in North America. C. J. Delp, ed. American Phytopathological Society, St. Paul, MN.

33. Köller, W., and Scheinpflug, H., 1987. Fungal resistance to sterol biosynthesis inhibitors: a new challenge. Plant Dis. 71:1066-1074.

34. Leung, H., Nelson, R. J., and Leach J. E. 1993. Population structure of plant pathogenic fungi and bacteria. Adv. Plant Pathol. 10:157-205.

35. Lucas, G. B. 1955. The cardinal temperatures and $\mathrm{pH}$ response of Thielaviopsis basicola. Mycologia 47:793-798.

36. McKay, A. H., Förster, H., and Adaskaveg, J. E. 2007. Sensitivity of isolates of Geotrichum citri-aurantii, the causal pathogen of sour rot in citrus, to DMI fungicides. (Abstr.) Phytopathology 97:S74.

37. McKay, A. H., Förster, H., Nguyen, N., and Adaskaveg, J. E. 2011. Molecular identification of Galactomyces species and population structure of the two postharvest sour rot pathogens of fruit crops in California. (Abstr.) Phytopathology 101:S118.

38. Parker, J. E., Warrilow, A. G., Cools, H. J., Martel, C. M., Nes, W. D., Fraaije, B. A., Lucas, J. A., Kelly, D. E., and Kelly, S. L. 2011. Mechanism of binding of prothioconazole to Mycosphaerella graminicola CYP51 differs from that of other azole antifungals. Appl. Environ. Microbiol. $77: 1460-1465$.

39. Russell, P. E., 2004. Sensitivity Baselines in fungicide resistance research and management. In: Fungic. Resist. Action Comm. Monogr. 3. Crop Life International, Brussels.

40. Scheinpflug, H. 1988. History of DMI fungicides and monitoring for resistance. Pages 77-78 in: Fungicide Resistance in North America. C. J. Delp, ed. American Phytopathological Society, St. Paul, MN.

41. Scott, D. W. 1979. On optimal and data-based histograms. Biometrika 66:605-610.

42. Siegel, M. R., Kerkenaar, A., and Kaars Sijpesteijn, A. 1977. Antifungal activity of the systemic fungicide imazalil. Neth. J. Plant Pathol. 83(Suppl. 1):121-133.

43. Smilanick, J. L., Mansour, M. F., Margosan, D. A., Gabler, F. M., and Goodwine, W. R. 2005. Influence of $\mathrm{pH}$ and $\mathrm{NaHCO}_{3}$ on effectiveness of imazalil to inhibit germination of Penicillium digitatum and to control postharvest green mold on citrus fruit. Plant Dis. 89:640-648.

44. Smilanick, J. L., and Sorenson, D. 2001. Control of postharvest decay of citrus fruit with calcium polysulfide. Postharvest Biol. Technol. 21:157-168.

45. Smilanick, J. L., Sorenson, D., Mansour, M., Aieyabei, J., and Plaza, P. 2003. Impact of a brief postharvest hot water drench treatment on decay, fruit appearance, and microbe populations of California lemons and oranges. HortTechnology 13:333-338.

46. Suprapta, D. N., Arai, K., and Iwai, H. 1996. Some physiological properties of citrus and noncitrus races of Geotrichum candidum isolated from soil in Japan. Mycoscience 37:401-407.

47. Tomlin, C. D. S. 2003. The Pesticide Manual, 13th edition. British Crop Protection Council, Alton, UK.

48. Wild, B. L. 1992. Variations in sensitivity of isolates of Geotrichum candidum to the fungicide guazatine. Australas. Plant Pathol. 21:13-15. 